ПРАКТИЧНИЙ АСПЕКТ ФОРМУВАННЯ НАВИЧОК 4К НА УРОКАХ ЧИТАННЯ В НУШ

\title{
PRACTICAL ASPECT OF FORMING 4C SKILLS IN READING LESSONS IN NUS
}

УДК 373:3.015.31:811.161.2 DOI https://doi.org/10.32843/2663$6085 / 2021 / 32-2.5$

\section{Кириленко О.С.,}

магістрантка фракультету дошкільної, початкової освіти і мистецтв Національного університету «Чернігівський колегіум» імені Т.Г. Шевченка

\section{Барнич О.В.}

канд. пед. наук, доцент, доцент кафедри мов і методики їх викладання Національного університету «Чернігівський колегіум» імені Т.Г. Шевченка

\section{Мамчич О.Б.,}

канд. пед. наук, доцент, завідувач кафедри мов і методики їх викладання Національного університету «Чернігівський колегіум» імені Т.Г. Шевченка
Дослідження є спрямованим на комплексний аналіз практичного аспекту фрормування навичок 4K (креативність, критичне мислення, кооперація та комунікативні навички) на уроках читання в Новій українській школі. Проаналізовано складники формули «4К» у взаємозв'язку та взаємовплив. Обґрунтовано необхідність розвитку 4К навичок із метою подолання творчої інертності, стереотипності та шаблонності мислення, фрормування продуктивних взаємин у колективі здобувачів освіти та розвитку навичок, що сприяють становленню ефективного співрозмовника та слухача, такого, який є здатним продуктивно комунікувати з оточенням, тактовно відстоювати власні позиції та знаходити компроміс. Акцентовано на потенціалі уроків читання для розвитку 4 навичок завдяки якісній, творчій, багаторівневій, комплексній роботі 3 художнім текстом. Рекомендовано перелік вправ та завдань, використання яких сприятиме розвитку критичності та креативності мислення учнів на уроках читання в Новій українській школі. Визначено переваги командної роботи перед індивідуальною, вказано шляхи організації кооперації під час проєктної роботи над текстовим матеріалом сучасних підручників для читання. Описано потенціал уроків читання для розвитку та удосконалення комунікативних навичок учнів як під час аналізу художнього твору чи його персонажів, так і під час моделювання різноманітних комунікативних ситуацій на основі прочитаного чи прослуханого тексту. Визначено можливості для одночасного фрормування складників 4 К моделі під час виконання нестандартних завдань до тексту за рахунок поєднання креативності мислення, його гнучкості та спрямованості на пошук цікавих рішень, командної роботи, яка може являти собою як розподіл обов'язків, так і послідовне узгоджене виконання дій, комунікативних навичок, що є визначальним компонентом для налагодження ефрективної кооперацій та згуртування команди.
Ключові слова: 4 навички, креативність, критичне мислення, кооперація, комунікативні навички, урок читання, НУШ.

The research is aimed at a comprehensive analysis of the practical aspect of the $4 \mathrm{C}$ skills formation (creativity, critical thinking, cooperation and communication skills) in reading lessons in the New Ukrainian School. The components of the $" 4 C$ » formula are analyzed in their relationship and the possibility of interaction. The need to develop 4C skills is substantiated, it is aimed to overcome creative inertia, stereotypes and formulaic thinking, the formation of productive relationships in the team of applicants for education and the development of skills that contribute to the formation of an effective interlocutor and listener. The one who is able to communicate productively with the environment, tactfully defend their own positions and find a compromise. Emphasis is placed on the potential of reading lessons for the development of $4 \mathrm{C}$ skills through qualitative, creative, multilevel, comprehensive work with literary text. A list of exercises and tasks is recommended, the use of which will promote the development of critical and creative thinking of pupils in reading lessons at the New Ukrainian School. The advantages of team work over individual work are determined, the ways of cooperation organization during project work on the textual material of modern textbooks for reading are indicated. The potential of reading lessons for the development and improvement of pupils communication skills is described both during the analysis of a work of art or its characters, and during the modeling of various communicative situations based on the read or listened text. Possibilities for simultaneous formation of $4 \mathrm{C}$ mode components during non-standard tasks to the text due to the combination of creative thinking, its flexibility and focus on finding interesting solutions, teamwork, which can be both division of responsibilities and consistent coordinated performance of actions, communication skills, which are a key component for establishing effective cooperation and team building

Key words: $4 C$ skills, creativity, critical thinking, cooperation, communication skills, reading lesson, NUS.
Постановка проблеми у загальному вигляді. Основною метою освіти XXI століття $€$ фрормування особистості на засадах компетентного підходу, зорієнтованість не на теоретизацію освітнього процесу, а на практичну цінність отриманих знань та здатність оперувати ними в нових умовах, а не лише за зразком. Сучасні учні мають швидко пристосовуватись до світу, який постійно змінюється, вміти дивергентно мислити, працювати в команді та комунікувати на найбільш продуктивному рівні. У цьому зв'язку Нова українська школа акцентує увагу педагогів на необхідності розвитку навичок 4К (креативність, критичне мис- лення, кооперація та комунікативні навички). Ці навички дають дитині змогу самореалізуватися, навчитися розглядати ситуації 3 різних сторін і знаходити варіанти їх вирішення, працювати в команді, вміти фрормулювати і висловлювати свою думку.

Аналіз останніх досліджень і публікацій. Основою нашого дослідження є здобутки таких учених: В. Моляка, В. Дружиніна, Д. Богоявленської, С. Сисоєвої, М. Холодної, К. Поппера, П. Ленсіоні, К. Ушинського, Дж. Гілфрорда та ін. У дослідженні ми використовували такий метод, як аналіз наукових джерел. 
Виділення не вирішених раніше частин загальної проблеми. Незважаючи на те, що окремо проблеми розвитку креативності, критичного мислення, кооперації та комунікативних навичок розглядались значною кількістю дослідників, питання інтеграції цих складників до моделі «4К» не $є$ повністю дослідженим та потребує вивчення.

Мета статті полягає в розкритті практичного аспекту фрормування навичок 4K на уроках читання в НУШ.

Виклад основного матеріалу. На уроках читання в Новій українській школі здійснюється комплексний розвиток навичок 4K (креативність, критичне мислення, кооперація та комунікативні навички). Формування кожного складника цих навичок є невід'ємною частиною навчального процесу, тому нижче ми розкриємо особливості практичної сторони розвитку кожного компоненту.

О. Бєлкіна-Ковальчук трактує критичне мислення як здатність людини самостійно оцінювати явища навколишньої дійсності, інфрормацію, наукові знання, думки інших людей, а також тяжіння до більш оптимального розв'язку проблем, до перегляду наявних стереотипів, традицій [1].

Основними ознаками учня, який критично мислить, є: гнучкість мислення, наполегливість, готовність виправляти власні помилки, пошук компромісних рішень, здатність до планування, швидке усвідомлення поставленої проблеми, оригінальність [1].

В умовах НУШ $є$ важливим подолання стереотипності мислення. Учитель добирає спеціальні завдання, які дають змогу розглянути певну ситуацію 3 різних сторін. Педагог має створити такі умови, щоб кожен учень не боявся висловити свою думку (варіант вирішення проблеми), навіть якщо вона $€$ абсурдною. У класі завжди має бути сприятлива психологічна атмосорера.

Критичне мислення формується насамперед у дискусіях, а також за умови активної взаємодії 3 текстами. Структура уроку критичного мислення на уроці читання включає 3 етапи.

1. Актуалізація - стимулювання зацікавленості дітей, пригадування знань, які будуть корисними на цьому уроці. Найбільш оптимальними для цього етапу є такі стратегії:

1) кластер - це графрічна фрорма організації інсрормації, коли виділяються основні смислові одиниці, які фріксуються у вигляді схеми 3 позначенням всіх зв'язків між ними;

2) асоціативний кущ;

3) дерево передбачень;

4) таблиця «ЗХД» (Знаємо - Хочемо дізнатись - Дізнались);

5) мозковий штурм;

6) робота в парах;

7) кошик ідей;

8) передбачення на основі опорних слів;
9) діаграма Венна - прийом для зіставлення, порівняння, знаходження спільних рис, явищ, ознак у поняттях, образах літературних героїв. Основний сенс застосування прийому в технології розвитку критичного мислення полягає в тому, що порівняння, тобто характеристики, за якими учні порівнюють різні явища, об'єкти та інше, фрормулюють самі учні [6].

2. Осмислення - основна частина уроку. Прийоми, які можна використовувати на цьому етапі:

1) карта поняття;

2) читаємо в парах;

3) подвійний щоденник;

4) читання з маркуванням;

5) опорні слова;

6) Т-таблиця;

7) картографрування тексту;

8) спитайте в автора;

9) ажурна пилка

10) дискусія [6]

3. Останній етап уроку критичного мислення рефрлексія або підбиття підсумків. На цьому етапі доречно використовувати такі вправи, які допоможуть дитині зробити висновки, систематизувати матеріал, оцінити свою роботу на уроці, а саме:

1) сенкан;

2) кластер;

3) займи позицію;

4) ПРЕС;

5) шкала думок;

6) фріш-бон (риб'яча кістка);

7) бортовий журнал [6].

Нині існує чимало вправ і прийомів для розвитку критичного мислення. Ми перелічили тільки найпоширеніші. Використання цих вправ допоможе вчителю урізноманітнити уроки читання, а також розвинути логічне мислення, пам'ять, уяву здобувачів освіти.

Важливим компонентом навичок 4K є креативність. Креативність трактується вченими як розумова і практична діяльність, результатом якої $€$ створення нових, оригінальних ідей. Креативне мислення дає змогу дитині знаходити вихід із нестандартних ситуацій, руйнувати стереотипи, виявляти свої творчі здібності. У початкових класах проводиться активна робота з розвитку креативності на уроках читання [5]. Основною метою розвитку креативного мислення $€$ самореалізація особистості. Нижче наводимо види вправ для розвитку креативного мислення на уроках читання в НУШ.

1. Складання історії з випадкових слів. Для цього необхідно дібрати 4-8 випадкових слів. Ці слова можна дібрати випадково з художнього твору, що ви вивчаєте на уроці, або самостійно придумати з учнями. Потім із цими словами потрібно скласти історію. Наприклад, є слова «сніг», «ворона», «книга», «небо», «дерево». Створюємо історію: 
«Сьогодні цілу ніч йшов сніг. Уранці цю зимову красу побачила ворона, яку звали Кар. «Яка краса!» - захоплено каркнула ворона. Вона звернула увагу, що на засніженій доріжці лежить книга. «Звідки взялася ця книга? Неначе впала 3 неба». - задумалась Кар. Самотнє дерево тільки похитало гілками».

2. Гра «Передбачення». На уроках читання передбачення може бути за заголовком художнього твору, за початком твору і за уривком із твору. Сучасні підручники пропонують учням багато завдань на прогнозування. Наприклад, у підручнику автора Оксани Вашуленко «Українська мова та читання» для 3 класу до казки «Найцінніший подарунок» дітям пропонується завдання за заголовком і ілюстрацією до твору спрогнозувати, який саме подарунок є найціннішим.

3. Гра «Дитячий театр». Учитель пропонує за допомого міміки, жестів і імітації передати події, що відбуваються у творі. Наприклад, педагог пропонує передати зміст казки «Колобок», не вживаючи слів.

4. Гра «що спочатку, що в кінці». Учитель зачитує уривок з твору, а учні називають ті події, які відбулися раніше чи пізніше. Наприклад: «От вона й написала до батька: «€, тату, в Києві чоловік, на ймення Кирило, на прізвище Кожум'яка. Він один тільки може змія подолати». Після цього вчитель ставить запитання:

- Що сталося раніше?

- Що станеться пізніше?

5. Гра «Намалюємо мультфільм». Учитель пропонує дітям об'єднатися в 4 групи і дає кожній групі назву казки, яку вони читали раніше. Далі дає завдання зобразити події цього твору на малюнку. Інші групи мають відгадати, яку саме казку зображено.

6. Гра «3 цифрерблатом я дружу - зразу відповідь скажу». Учитель ставить дітям запитання за змістом твору, а учні вказують на відповідь за допомогою стрілки циферблату. Наприклад (казка «Зачарована красуня»):

- Скільки дітей було в короля і королеви? (1)

- Скільки феей запросили на бенкет? (12)

- Скільки феей забули запросити в палац? (1)

7. Гра «Юний казкар». Учитель пропонує учням написати свій твір, взявши одну дійову особу 3 одного твору, а другу - 3 іншого, а сюжет казки відтворити, як у третьому. Наприклад: головний герой - Попелюшка, інший герой - Нехайко, сюжет казки «Котигорошко» [5].

Отже, можна зробити висновок, що використання вправ на розвиток креативного мислення на уроках читання розвиває в дітей уяву, франтазію, пам'ять, а також мотивує до самостійного читання творів.

Кооперація, або командна праця, - це форма організації навчально-пізнавальної діяльності на уроці, що має на меті спільне планування, взаємоконтроль, взаємонавчання учнів під опосередкованим керівництвом вчителя. Під час командної співпраці потрібно створювати такі ситуації, в яких дитина буде почуватися успішною. Перевагами командної роботи є:

- взаємодія між учнями, в результаті якої дитина набуває соціальних навичок;

- розвиток комунікативних навичок;

- можливість виконати набагато більшу частину завдань за короткий час;

- фрормування вміння самоконтролю, самоорганізації [4].

Важливу роль для фрормування навичок роботи в команді відіграє створення учнями проєктів на уроках читання. Підручник Олени Вашуленко для 3 класу «Українська мова та читання» пропонує такі проєктні завдання:

1) підготувати виставку дитячих журналів;

2) написати слоган (текст реклами) для одного 3 журналів;

3) намалювати рекламний плакат до журналу, який читаєте;

4) дослідити, які чарівні казки є у вас вдома і у бібліотеці;

5) скласти власну чарівну казку;

6) підготувати і провести презентацію героїв казки, які вам найбільше сподобались [2].

У процесі роботи над проєктом діти вчаться працювати в групах, знаходити спільну думку, компроміс. Перед початком уроку вчитель нагадує учням правила роботі в групі:

1) виявляти взаємоповагу до всіх учасників;

2) бути активним під час обговорення;

3) користуватися правилом піднесеної руки;

4) не перебивати товаришів, коли вони висловлюють свою думку;

5) працювати так, щоб не заважати іншим учасникам;

6) звертатися за допомогою до товаришів, якщо щось незрозуміло [4].

У підручнику для 3 класу пропонується багато завдань для роботи в групах і парах. Наприклад:

1. Перевірка того, наскільки уважними були читачі. Скільки разів у тексті вжито певне слово?

2. Поставити одне одному запитання за прочитаним твором.

3. Обговорення різних дискусійних питань у групах.

4. Поділити текст на частини в групах і дати їм назву.

5. Обговорення прислів"їв у групах.

6. Підготувати і прочитати вірш в особах.

7. Дізнатися у свого сусіда по парті, який епізод твору йому сподобався найбільше.

Отже, можна зробити висновок, що командна праця відіграє важливу роль у формуванні особистості школяра. Працюючи в парі, групі, учні навча- 
ються висловлювати власну думку і прислухатися до думок інших.

Основним завданням уроку читання $€$ форомування комунікативних навичок учнів. У початковій школі мовленнєвий розвиток має спиратися на систему теоретичних знань, які потім будуть використані під час практичного спілкування. Для розвитку комунікативних навичок учнів можна використовувати такі завдання:

1) обговорення дискусійних питань;

2) вираження власного ставлення до головного героя твору;

3) постановка запитань за змістом твору до свого сусіда по парті;

4) творчий переказ твору;

5) презентація проєктів;

6) обговорення позитивних і негативних якостей головного героя;

7) обговорення ілюстрацій до тексту;

8) прогнозування змісту твору;

9) інсценізація;

10) читання в ролях.

Безперечно, комунікативні навички найкраще розвиваються у командній праці та виявляються під час завдань, що є орієнтованими на розвиток креативності та критичності мислення, що й робить їх ключовими в системі навичок 4К.

Висновки. Отже, навички 4К - це важливий полікомпонентний складник сучасного освітнього процесу. Сорормованість навичок 4K дає дитині змогу гнучко мислити, пристосовуватись до нових умов, знаходити вихід із різних ситуацій, оволодівати вмінням правильно формулювати і висловлювати власну думку. Сучасний учитель має фрормувати ці чотири навички комплексно. Основний принцип фрормування навичок 4K на уроці читання - це систематичність, оскільки тільки постійна робота над розвитком учнів сприятиме становленню всебічно розвиненої, успішної особистості.

\section{БІБЛІОГРАФІЧНИЙ СПИСОК:}

1. Большакова І. Технологія розвитку критичного мислення в початковій школі: вебінар. URL: https:// www.youtube.com/watch?v=xgp4TUfQudE (дата звернення: 12. 02. 2021).

2. Вашуленко О. Українська мова та читання: підручник для 3 класу закладів загальної середньої освіти (у 2-х частинах). Ч. 2. Видавничий дім «Освіта», 2020. 160 c.

3. Концепція нової української школи. URL: https:// mon.gov.ua/storage/app/media/zagalna\%20serednya/ nova-ukrainska-shkola-compressed.pdf (дата звернення: 13.02.2021).

4. Перун В. Методичні особливості парної та групової роботи на уроках літературного читання. URL: $\quad$ https://naurok.com.ua/metodichni-osoblivostiparno-ta-grupovo-roboti-na-urokah-literaturnogochitannya-92477.html (дата звернення: 13.02.2021).

5. Піцик Т. Дидактичні ігри та цікаві творчі завдання на уроках літературного читання. URL: https:// naurok.com.ua/materiali-do-urokiv-didaktichni-igrita-cikavi-tvorchi-zavdannya-na-urokah-literaturnogochitannya-75424.html (дата звернення: 13.02.2021).

6. Пометун. О. Як розвивати критичне мислення в учнів (з прикладом уроку). URL: https://nus.org. ua/articles/krytychne-myslennya-2/ (дата звернення: 12.02.2021).

7. Світилко А. Стратегії «РАФТ», «Діаграма Вена», «Асоціативний кущ». URL: https://vseosvita.ua/library/ strategii-raft-diagrama-vena-asociativnij-kus-74894. html (дата звернення: 13.02.2021). 